\title{
Synthesis of Amorphous Mesoporous Aluminosilicates from Bintan's Red Mud as Alumina Source
}

\author{
Futri Wulandari ${ }^{1,2}$, Eka Putra Ramdhani ${ }^{3}$, Yatim Lailun Ni'mah', \\ Ahmad Anwarud Dawam ${ }^{1}$, and Didik Prasetyoko, ${ }^{1, *}$

\begin{abstract}
${ }^{1}$ Department of Chemistry, Faculty of Mathematics and Natural Sciences, Institut Teknologi Sepuluh Nopember, Keputih, Sukolilo, Surabaya 60111, Indonesia

${ }^{2}$ Department of Environmental Engineering, Faculty of Civil Engineering and Planning, University of Science and Technology Jayapura, Jl. Raya Sentani - Padang Bulan, Abepura, Vim, Abepura, Jayapura 99224, Papua, Indonesia J. Politeknik Km. 24, Senggarang, Tanjung Pinang, Kepulauan Riau 29115, Indonesia
\end{abstract} \\ ${ }^{3}$ Department of Chemistry Education, Faculty of Teacher Training and Education, Universitas Maritim Raja Ali Haji,
}

Received May 22, 2017; Accepted January 10, 2018

\begin{abstract}
Red mud is a generated by-product in alumina production from bauxite ore. In this study, Bintan's red mud has been used as alumina and silica source to synthesize amorphous mesoporous aluminosilicates material. Alkali fusion method with a NaOH/red mud ratio $0.8 ; 1.0 ; 1.2 ; 1.4$ and 1.5 followed by hydrolysis method was used to extract dissolved alumina and silica from red mud. Synthesis of amorphous aluminosilicates by hydrothermal method was conducted at $80^{\circ} \mathrm{C}$ for $24 \mathrm{~h}$. Cetyltrimethylammonium bromide (CTABr) was added as the structure directing agent. Aluminosilicate products were characterized using FTIR spectroscopy (Fourier Transform Infra-Red Spectroscopy), XRD (X-ray Diffraction), SEM (Scanning Electron Microscopy), and nitrogen adsorption-desorption. $X R D$ and SEM result shows that the product was amorphous with low uniformity in terms of surface morphology and particle size. Nitrogen adsorption-desorption profile shows that all aluminosilicates products has a meso pore structure, confirmed by the highest pore distribution at 3.05-17.70 nm. The highest surface area and pore volume were obtained in ASM $0.8\left(\mathrm{NaOH} /\right.$ red mud ratio = 0.8) i.e. $177.97 \mathrm{~m}^{2} / \mathrm{g}$ and $1.09 \mathrm{~cm}^{3} / \mathrm{g}$, respectively.
\end{abstract}

Keywords: red mud; amorphous aluminosilicates; alkali fusion; CTABr

\section{ABSTRAK}

Red mud merupakan produk samping yang dihasilkan dari proses pengolahan bijih bauksit untuk memproduksi alumina. Pada penelitian ini, red mud Pulau Bintan digunakan sebagai sumber alumina dan silika untuk mensintesis material aluminosilikat mesopori amorf. Metode alkali fusi dengan rasio $\mathrm{NaOH} /$ red mud 0,8; 1,0; 1,2; 1,4 dan 1,5 diikuti dengan metode hidrolisis digunakan untuk mengekstrak alumina dan silika terlarut dari red mud. Aluminosilikat amorf disintesis dengan metode hidrotermal pada temperatur $80{ }^{\circ} \mathrm{C}$ selama 24 jam. Cetyltrimethylammonium bromide (CTABr) ditambahkan sebagai agen pengarah struktur. Produk aluminosilikat dikarakterisari menggunakan spektroskopi FTIR (Fourier Transform Infra-Red Spectroscopy), XRD (X-ray Diffraction), SEM (Scanning Electron Microscopy), dan adsorspsi-desorpsi nitrogen. Hasil XRD dan SEM memperlihatkan bahwa produk aluminosilikat yang dihasilkan adalah amorf dengan keseragaman morfologi permukaaan dan ukuran partikel yang rendah. Profil adsorpsi-desorpsi nitrogen menunjukkan bahwa semua sampel aluminosilikat mesopori yang dihasilkan merupakan padatan mesopori, yang dikonfirmasi dengan distribusi pori tertinggi pada 3,05-17,70 nm. Luas permukaan mesopori dan volume pori terbesar diperoleh pada sampel ASM 0,8 $(\mathrm{NaOH} /$ red mud ratio $=0,8)$ yaitu sebesar $177,97 \mathrm{~m}^{2} / \mathrm{g}$ dan $1,09 \mathrm{~cm}^{3} / \mathrm{g}$.

Kata Kunci: red mud; aluminosilikat amorf; fusi alkali; CTABr

\section{INTRODUCTION}

Red mud is a by-product from alumina production through Bayer process. Approximately, 35-40\% of the processed bauxite ore goes into the waste as alkaline red mud slurry which consists of $15-40 \%$ solids. About 0.8-1.5 tons of red mud was generated per ton of produced alumina [1]. Red mud is a highly alkaline waste material with $\mathrm{pH} 10-12.5$. Red mud have very fine particle size $(\leq 10.0 \mathrm{~mm})$ that contain aluminum,

* Corresponding author.

DOI: 10.22146/ijc.25184

Email address : didikp@chem.its.ac.id

Futri Wulandari et al. 
iron, silicon, titanium oxides and hydroxides [2]. Due to its chemical and mineralogical contents, this solid waste causes a significant impact on the environment and thus, proper disposal of red mud waste presents a huge challenge in alumina industries. Many attempts have been made over past years to find some practical applications for red mud utilization. Several studies have been carried out by using red mud as a catalyst [3], materials for catalysts and catalyst supports [4], building materials [5], inorganic substrates [6], adsorbent [7], ceramics [8], and dyes and paints [9].

Bintan Island is one of the place in Indonesia with a high activity of bauxite mining. The main contents of Bintan's red mud are $\mathrm{Fe}_{2} \mathrm{O}_{3}(44.65 \%), \mathrm{Al}_{2} \mathrm{O}_{3}(28.87 \%)$, $\mathrm{SiO}_{2}(20.20 \%)$, and some minor components, such as $\mathrm{TiO}_{2}, \mathrm{ZrO}_{2}, \mathrm{NiO}$ and $\mathrm{P}_{2} \mathrm{O}_{5}$ [10]. The high content of alumina $\left(\mathrm{Al}_{2} \mathrm{O}_{3}\right)$ and silica $\left(\mathrm{SiO}_{2}\right)$ in Bintan's red mud can be used as a source for the synthesis of aluminosilicate material.

Aluminosilicates materials have been widely applied as catalysts [11], adsorbents [12], material for aluminosilicate-zeolite [13] production, and siliceouszeolite membranes production [[14]. Aluminosilicates material can be synthesized using various methods, such as hydrothermal [15], recrystallization [16], sol-gel followed by hydrothermal [17] and alkali extraction [18] methods. Synthetic methods of aluminosilicates from pure chemicals have been widely explored by many researchers from all around the world. There have also been several reports on synthesis of aluminosilicates material using natural and waste materials, such as using K-feldspar [19], rice husk ash [20], natural clay [18] and kaolin [21]. However, study on the synthesis of amorphous aluminosilicates using natural raw materials remains insufficient. For instance, synthesis of aluminosilicate material using red mud as a source of alumina and silica itself has not been investigated before.

The most significant problem exploiting red mud as the precursor material to synthesize aluminosilicates material is the difficulty of iron oxide $\left(\mathrm{Fe}_{2} \mathrm{O}_{3}\right)$ and other impurities removal from red mud. Iron oxide must be firstly separated in order to easily extract alumina and silica. Alkali fusion method can be used to resolve this kind of problem [22]. The main principles of alkali fusion reaction is the reaction between alumina and silica with alkali bases $(\mathrm{NaOH})$ at high temperatures $\left(500-650{ }^{\circ} \mathrm{C}\right)$. Alumina and silica have to be fused together to form natrium-aluminate and silicate salts, which have a high solubility in water.
Here, we report the synthesis of amorphous aluminosilicate using red mud from Bintan Island as aluminum and silicon sources via alkali fusion method. In order to study the effect of ratio $\mathrm{NaOH}$ in alumina extraction process, $\mathrm{NaOH} / \mathrm{red}$ mud ratio was varied $0.8 ; 1.0 ; 1.2 ; 1.4$ and 1.5 .

\section{EXPERIMENTAL SECTION}

\section{Materials}

The raw material, red mud, was obtained from Bintan Island, Indonesia. The chemical compositions of red mud determined by an X-ray fluorescence spectrometer (XRF, PANalytical, Minipal 4) are listed in Table 1.

All chemicals were analytical grade and used without further purification: $\mathrm{NaOH}$ (sodium hydroxide, Applichem, N 99.5\%); LUDOX (colloidal silica, $\mathrm{SiO}_{2}$, Aldrich, 30\%); tetrapropylammonium hydroxide (TPAOH, $1 \mathrm{~L}=1.00 \mathrm{~kg}, 40 \mathrm{wt} \%$ solution in water),distilled water; CTABr (cetyltrimethylammonium bromide, $\mathrm{C}_{19} \mathrm{H}_{42} \mathrm{BrN}$, Applichem, 99\%).

\section{Instrumentation}

The IR spectra were recorded using Fourier Transform Infrared spectroscopy (FTIR, Shimadzu Instrument Spectrum One 8400S) through $\mathrm{KBr}$ pellet method. Powder X-ray diffraction pattern was obtained from Phillips Expert with $\mathrm{Cu} \mathrm{Ka}$ radiation $(\lambda=1.54056$ $\AA$ ), voltage $40 \mathrm{kV}, 30 \mathrm{~mA}$ and $2 \theta=5-50^{\circ}$. Scanning electron microscope (SEM) was operated at an acceleration voltage of $20 \mathrm{kV}$ and working distance of 9 $\mathrm{mm}$. Compositional analysis were performed using energy-dispersive X-ray analyzer attached to the SEM (SEM-EDX) for $\mathrm{Al}, \mathrm{Si}, \mathrm{Na}$, and $\mathrm{O}$. Nitrogen physisorption isotherms were collected on a Quantachrome e-Corporation (Nova-1200). BrunauerEmmett-Teller (BET) calculations were used to determine the material surface area. Mesopore size distributions were calculated using the Barrett, Joyner, and Halenda $(\mathrm{BJH})$ method.

\section{Procedure}

\section{Alkali fusion of red mud and formation of $\mathrm{Na}$ - aluminate-silicate salt}

Dried red mud was mixed with $\mathrm{NaOH}(\mathrm{NaOH} / \mathrm{red}$ mud weight ratio $=0.8 ; 1.0 ; 1.2 ; 1.4 ; 1.5)$ and then

Table 1. Chemical composition of Bintan's red mud (RM) and red mud residue after fusion process (RRF 1.0) (wt.\%)

\begin{tabular}{lllllllllll}
\hline Sample & $\mathrm{Fe}_{2} \mathrm{O}_{3}$ & $\mathrm{Al}_{2} \mathrm{O}_{3}$ & $\mathrm{SiO}_{2}$ & $\mathrm{TiO}_{2}$ & $\mathrm{P}_{2} \mathrm{O}_{5}$ & $\mathrm{~K}_{2} \mathrm{O}$ & $\mathrm{CaO}$ & $\mathrm{V}_{2} \mathrm{O}_{5}$ & $\mathrm{Cr}_{2} \mathrm{O}_{3}$ & $\mathrm{NiO}$ \\
\hline $\mathrm{RM}$ & 48.89 & 29.00 & 18.26 & 2.67 & 0.55 & 0.26 & 0.25 & 0.065 & 0.087 & 0.091 \\
$\mathrm{RRF}$ & 51.46 & 27.00 & 17.30 & 2.47 & 0.54 & 0.41 & 0.25 & 0.060 & 0.090 & 0.150 \\
\hline
\end{tabular}


transferred into stainless steel crucible. The mixture was then placed into the furnace and calcined at $600{ }^{\circ} \mathrm{C}$ for 2 h.

Formation of $\mathrm{Na}$-aluminate-silicate salt. The fusion product (fusion mass) was crushed and then dissolved into $127.5 \mathrm{~mL}$ of distilled water. The mixture was then placed into a polypropylene bottle and stirred for $24 \mathrm{~h}$ at room temperature to obtain dissolved $\mathrm{Al}$ and $\mathrm{Si}$. The mixture was then filtered to separate the filtrate (sources of $\mathrm{Al}$ and $\mathrm{Si}$ solution) and solid (residue). Then the filtrate was evaporated and dried to obtain solid $\mathrm{Na}$-aluminatesilicate feed. The solid (residue) was collected and then dried for XRD characterization.

\section{Synthesis of amorphous aluminosilicates}

Amorphous aluminosilicate (ASM) was prepared by a method of Hartati et al. [17] to obtain a highly active mesoporous aluminosilicate with molar ratio 1 $\mathrm{SiO}_{2}: 0.0125 \quad \mathrm{Al}_{2} \mathrm{O}_{3}: 0.2$, TPAOH:38 $\mathrm{H}_{2} \mathrm{O}$. Ludox was mixed with Na-silicate-aluminate feed in the polypropylene bottle and then stirred for $30 \mathrm{~min}$ to obtain a gel mixture. TPAOH and distilled water were added to the mixture and stirred for $15 \mathrm{~h}$ at room temperature. The mixture was then placed in oven and heated at 80 ${ }^{\circ} \mathrm{C}$ for $24 \mathrm{~h}$. After cooled to room temperature, $\mathrm{CTABr}$ were slowly added (molar ratio $\mathrm{SiO}_{2} / \mathrm{CTABr}=3.85$ ) and stirred for $30 \mathrm{~min}$ to obtain homogenous gel. The mixture then placed at room temperature for $4 \mathrm{~h}$. The solid products were separated by filtration and washed with distilled water until the $\mathrm{pH}$ of supernatant was 7 (neutral). The solid was then dried at $60^{\circ} \mathrm{C}$ for $24 \mathrm{~h}$. The final powder product was calcined at $550^{\circ} \mathrm{C}$ for $1 \mathrm{~h}$ in $\mathrm{N}_{2}$ and $6 \mathrm{~h}$ in air to remove any organic compounds.

\section{RESULT AND DISCUSSION}

Based on the XRF analysis, Bintan's red mud major and minor components composition can be seen in Table 1. $\mathrm{Fe}_{2} \mathrm{O}_{3}$ is the major component with the largest composition (48.89 wt.\%). High iron content could become impurities so it must be separated from red mud before further synthetic process. Another relatively large compound were $\mathrm{Al}_{2} \mathrm{O}_{3}$ and $\mathrm{SiO}_{2}$.

Alumina (gibbsite, $\left.\mathrm{Al}(\mathrm{OH})_{3}\right)$, boehmite $(\mathrm{\gamma}-\mathrm{AlO}(\mathrm{OH}))$ and silica $\left(\mathrm{SiO}_{2}\right.$ in quartz phase) have low solubility in water, so does $\mathrm{Fe}_{2} \mathrm{O}_{3}$. In order to separate iron content from red mud, first, red mud had to be treated with alkali fusion reaction to form alumina and silica salt with higher solubility in water, so alumina and silica can be easily extracted from red mud. After the fusion process, the fusion solid product was hydrolyzed using distilled water with the solid to liquid ratio of 1:5. In this process, alumina-silica salt would be dissolved in water so that the iron oxide $\left(\mathrm{Fe}_{2} \mathrm{O}_{3}\right)$ could be separated. Filtrate was

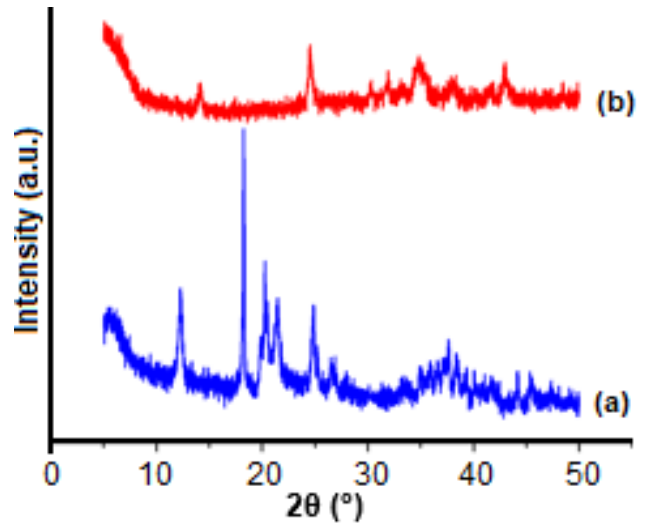

Fig 1. XRD pattern of (a) red mud (RM) and (b) red mud residue after fusion process (RRF 1.0)

evaporated and dried to obtained feed of $\mathrm{Na}$-aluminatesilicate (FF).

Fig. 1 shows the XRD pattern of red mud and red mud after alkali fusion process followed by aluminasilicate extraction with fusion ratio 1.0 (RRF 1.0). XRD pattern of red mud (Fig. 1a) showed that the main phase compound of red mud is hematite $\left(\mathrm{Fe}_{2} \mathrm{O}_{3}\right)$, gibbsite $\left(\mathrm{Al}(\mathrm{OH})_{3}\right)$, boehmite $(\mathrm{Y}-\mathrm{AlO}(\mathrm{OH}))$, anatase $\left(\mathrm{TiO}_{2}\right)$ and quartz $\left(\mathrm{SiO}_{2}\right)$. Hematite shows characteristic peak at $2 \theta=26^{\circ}$; boehmite at $2 \theta=18^{\circ}$; gibbsite at $2 \theta=$ $20^{\circ}$; quartz at $2 \theta=22^{\circ}$; and anatase at $2 \theta=28^{\circ}$. Fig. $1 \mathrm{~b}$ showed the pattern of red mud after alkali fusion process and extraction of alumina and silica. From this pattern, it can also be seen that the characteristic peaks of boehmite, gibbsite and quartz do not appear. This, indicates that alumina and silica had been successfully separated and extracted from red mud. These results were supported by red mud (RM) composition and red mud residues after the fusion process (RRF) data in Table 1. Based on the data, it can be seen that the hematite $\left(\mathrm{Fe}_{2} \mathrm{O}_{3}\right)$ composition has increased after the fusion process, whereas gibbsite/boehmite $\left(\mathrm{Al}_{2} \mathrm{O}_{3}\right)$ and quartz $\left(\mathrm{SiO}_{2}\right)$ decreased in composition.

EDX analysis was performed on Na-aluminatesilicate feed solids to determine the content of silicon (Si), aluminium ( $\mathrm{Al}$ ) and natrium $(\mathrm{Na})$ as a reference to determine the aluminosilicate formula. The composition of $\mathrm{Si}, \mathrm{Al}$ and $\mathrm{Na}$ on the Na-aluminate-silicate feed sample with the $\mathrm{NaOH} / \mathrm{RM}$ fusion ratio $(0.8 ; 1.0 ; 1.2$; 1.4 and 1.5) are shown in Table 2. The EDX results show that the percentage of aluminium (Al) in the $\mathrm{Na}$ aluminate-silicate feed is generally proportional to the $\mathrm{NaOH}$ to RM ratio. This indicates that more $\mathrm{NaOH}$ can dissolve and extract more Al from the red mud. Al has higher weight percentages than $\mathrm{Si}$ since the alumina salts $\left(\mathrm{NaAlO}_{2}\right)$ solubility in water is higher than silicate salts $\left(\mathrm{Na}_{2} \mathrm{SiO}_{3}\right)$. 
Table 2. EDX data of Na-aluminate-silicate feed (FF)

\begin{tabular}{cccccc}
\hline wt.\% & FF 0.8 & FF 1.0 & FF 1.2 & FF 1.4 & FF 1.5 \\
\hline $\mathrm{Na}$ & 18.86 & 13.76 & 17.01 & 18.21 & 26.26 \\
$\mathrm{Al}$ & 2.58 & 1.88 & 2.45 & 3.42 & 3.77 \\
$\mathrm{Si}$ & 0.31 & 0.22 & 0.25 & 0.18 & 0.24 \\
\hline
\end{tabular}

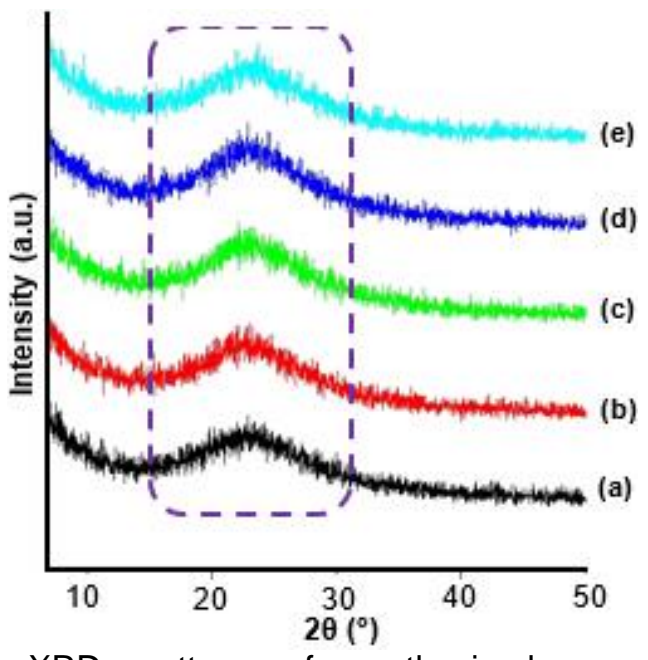

Fig 2. XRD pattern of synthesized amorphous aluminosilicate (AAM) from Bintan's red mud (a) AAM 0.8 ; (b) 1.0; (c) 1.2; (d) 1.4; and (e) 1.5

The next process was synthesis of amorphous mesoporous aluminosilicate from $\mathrm{Na}$-aluminate-silicate feed with a molar composition ratio of $1 \mathrm{SiO}_{2}: 0.0125$ $\mathrm{Al}_{2} \mathrm{O}_{3}: 0.2$ TPAOH:38 $\mathrm{H}_{2} \mathrm{O}$. The calculated ratio composition for synthesis is based on the EDX data of $\mathrm{Si}, \mathrm{Al}$ and $\mathrm{Na}$ composition. The XRD pattern of the synthesized amorphous aluminosilicate (AAM) from Bintan's red mud is shown at Fig. 2. The diffraction patterns presented in Fig. 2 indicate that all samples are essentially amorphous, marked by the existence of a broad peak at $2 \theta$ in the range of $15-35^{\circ}$, which is attributed to the amorphous aluminosilicate [23].

Infrared (IR) spectroscopy was used to investigate the functional group characteristic of synthesized amorphous aluminosilicate before and after calcination. The interaction of $\mathrm{CTABr}$ templates with mesoporous surface walls and the formation of mesoporous structure were also studied using IR spectroscopy. The IR spectra of amorphous aluminosilicates before calcination (AAMSK) are shown in Fig. 3. Based on the spectra, all samples from the various $\mathrm{NaOH} / \mathrm{RM}$ fusion ratio (AAMSK 0.8; AAM-SK 1.0; AAM-SK 1.2; AAM-SK 1.4; AAMSK 1.5) have identical spectra, i.e. no significant change in the IR spectra from each sample. The shoulder bands around 3450 and $1635 \mathrm{~cm}^{-1}$ are assigned to the stretching vibrations of $-\mathrm{OH}$ bond from the water molecules and silanol group, respectively. The absorption bands around 2920, 2850,912 and $752 \mathrm{~cm}^{-1}$ are attributed to the symmetric and asymmetric stretching

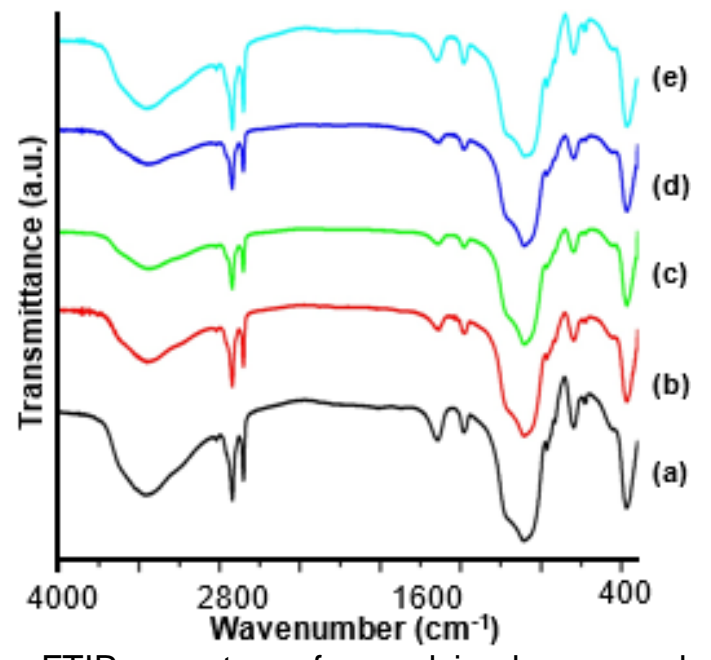

Fig 3. FTIR spectra of uncalcined amorphous aluminosilicate (a) AAM-SK 0.8; (b) 1.0; (c) 1.2; (d) 1.4; and (e) 1.5

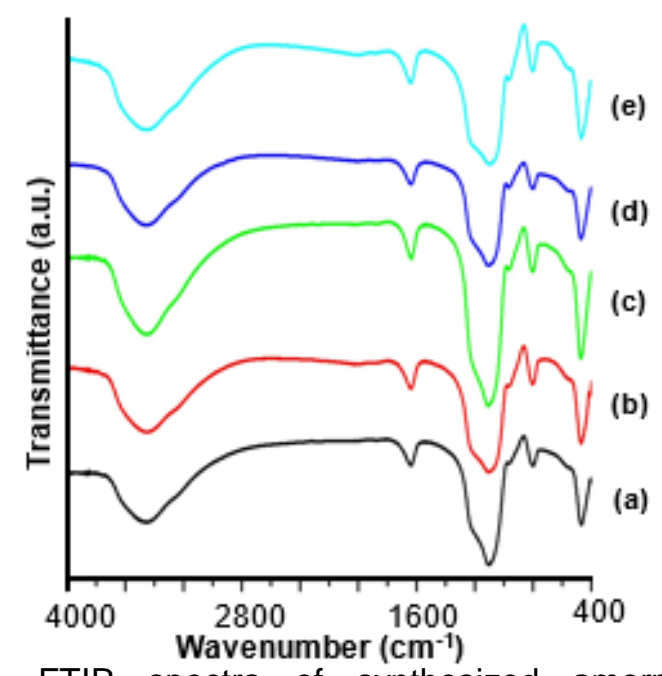

Fig 4. FTIR spectra of synthesized amorphous aluminosilicate (a) AAM 0.8; (b) 1.0; (c) 1.2; (d) 1.4; and (e) 1.5

of CTABr molecules from C-H (2950-2840 $\left.\mathrm{cm}^{-1}\right)$, C-N and $\mathrm{N}-\mathrm{H}$ bending, respectively. The IR spectra of AAMSK samples also have bands around 1103, 794 and $460 \mathrm{~cm}^{-1}$ that correspond to the asymmetric stretching of $\mathrm{Si}-\mathrm{O}-\mathrm{Si} / \mathrm{Si}-\mathrm{O}-\mathrm{Al}$ bond and the bending vibration of $\mathrm{O}$ $\mathrm{Si}-\mathrm{O} / \mathrm{O}-\mathrm{Al}-\mathrm{O}$ bond, which are the characteristic of the aluminosilicates materials.

Fig. 4 shows the IR spectra of the amorphous mesoporous aluminosilicates samples after calcination 
Table 3. EDX data of synthesized amorphous aluminosilicates (AAM)

\begin{tabular}{cccccc}
\hline wt.\% & AAM 0.8 & AAM 1.0 & AAM 1.2 & AAM 1.4 & AAM 1.5 \\
\hline Si & 12.01 & 19.74 & 14.27 & 12.15 & 10.19 \\
$\mathrm{Al}$ & 0.73 & 0.90 & 0.64 & 1.79 & 0.40 \\
$\mathrm{Na}$ & 0.54 & 0.49 & 0.56 & 0.35 & 0.19 \\
$\mathrm{O}$ & 86.72 & 78.86 & 84.52 & 85.71 & 89.21 \\
\hline
\end{tabular}
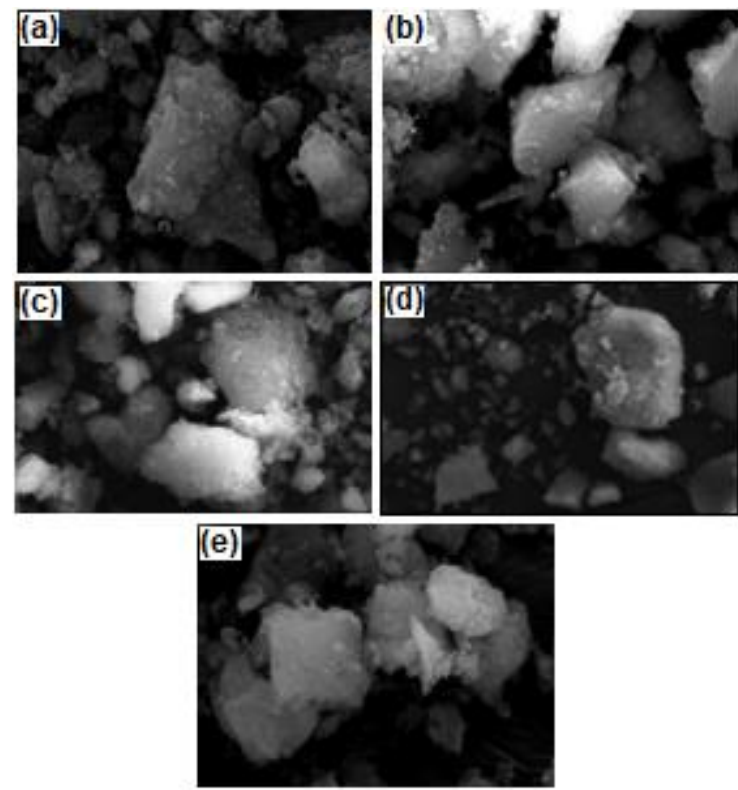

Fig 5. SEM images of the synthesized amorphous aluminosilicate (a) AAM 0.8; (b) 1.0; (c) 1.2; (d) 1.4; and (e) 1.5

(AAM). The IR spectra for all samples (AAM 0.8; 1.0; $1.2 ; 1.4$ and 1.5) show similar absorption peaks at around 3450, 1630, 1103, 790 and $470 \mathrm{~cm}^{-1}$. These absorption peaks correspond to the IR absorption peaks of the samples before calcination (AAM-SK). The characteristic peaks that correspond to $\mathrm{CTABr}$ molecules have disappeared. This indicates that $\mathrm{CTABr}$ molecules have been released from the aluminosilicates surface and leaving the pore structure on the samples. It is also supported by the appearance of the shoulder peak at around $960 \mathrm{~cm}^{-1}$, which is the characteristic for the vibration of silanol groups $(\mathrm{Si}-\mathrm{OH})$ on mesoporous wall surfaces, indicating that the mesoporous structure has been formed.

The morphologies of the synthesized amorphous mesoporous aluminosilicates (AAM) were observed by SEM, which is shown in Fig. 5. It is shown that all AAM samples particle have irregular shapes, low uniformity and narrow particle size distribution. It can also be seen that the surface of AAM particles is covered by aggregates. These results correspond to the XRD result that show the amorphous type of the synthesized aluminosilicate sample.

Energy Dispersive X-Ray (EDX) method was used to analyze the elemental contents of the all synthesized

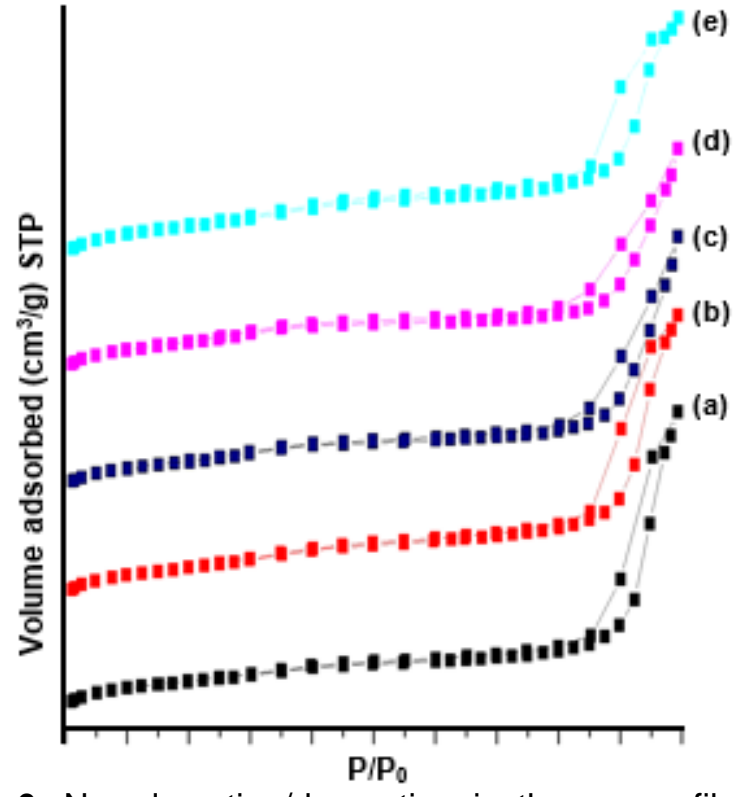

Fig 6. $\mathrm{N}_{2}$ adsorption/desorption isotherms profiles of AAM Sample (a) AAM 0.8; (b) 1.0; (c) 1.2; (d) 1.4; and (e) 1.5

amorphous aluminosilicates samples (AAM). The elemental contents based on EDX analysis results are listed in Table 3. Based on this result, it can be seen that all AAM samples consist of the elements that is used as precursors ( $\mathrm{Si}, \mathrm{Al}, \mathrm{Na}$ and $\mathrm{O}$ ), while no other elements are detected. It indicates that there is no atomic impurity in the synthesized sample; all of the synthesized amorphous mesoporous aluminate samples have high purity.

The $\mathrm{N}_{2}$ adsorption-desorption isotherm were carried out to determine the specific surface area, pore size distribution, total pore volume and pore structure of the synthesized amorphous mesoporous aluminosilicates materials. Fig. 6 and 7 show the $\mathrm{N}_{2}$ adsorption-desorption isotherm profiles and pore distribution of the synthesized amorphous mesoporous aluminosilicates samples. As displayed in Fig. 6, all samples exhibit two hysteresis loops, one of which is small hysteresis loop in the relatively low $\mathrm{P} / \mathrm{P}_{0}$ range of $0.30-0.60$, and the other larger hysteresis loop is encountered in the higher $\mathrm{P} / \mathrm{P}_{0}$ range from 0.80 to 1.0 , which is attributed to the mesoporous structures. Based on that adsorption and desorption pattern, it can also be concluded that all ASM samples exhibit an isotherm type IV profile [24]. The type IV isotherm is 
Table 4. The surface area, pore diameter and pore volume of AAM sample data

\begin{tabular}{ccccc}
\hline Sample & $\mathrm{S}_{\mathrm{BET}^{\mathrm{a}}}\left(\mathrm{m}^{2} / \mathrm{g}\right)$ & $\mathrm{S}_{\text {meso }}{ }^{\mathrm{b}}\left(\mathrm{m}^{2} / \mathrm{g}\right)$ & $\mathrm{D}_{\text {meso }^{\mathrm{c}}}(\mathrm{nm})$ & $\mathrm{V}_{\text {meso }}{ }^{\mathrm{d}}\left(\mathrm{cm}^{3} / \mathrm{g}\right)$ \\
\hline AAM 0.8 & 371.08 & 177.94 & $3.05 ; 17.60$ & 1.09 \\
AAM 1.0 & 400.34 & 175.31 & $3.41 ; 17.70$ & 1.04 \\
AAM 1.2 & 362.55 & 147.68 & $3.06 ; 17.60$ & 0.93 \\
AAM 1.4 & 418.02 & 129.84 & $3.05 ; 17.65$ & 0.85 \\
AAM 1.5 & 445.71 & 176.44 & $3.42 ; 17.61$ & 0.97 \\
\hline
\end{tabular}

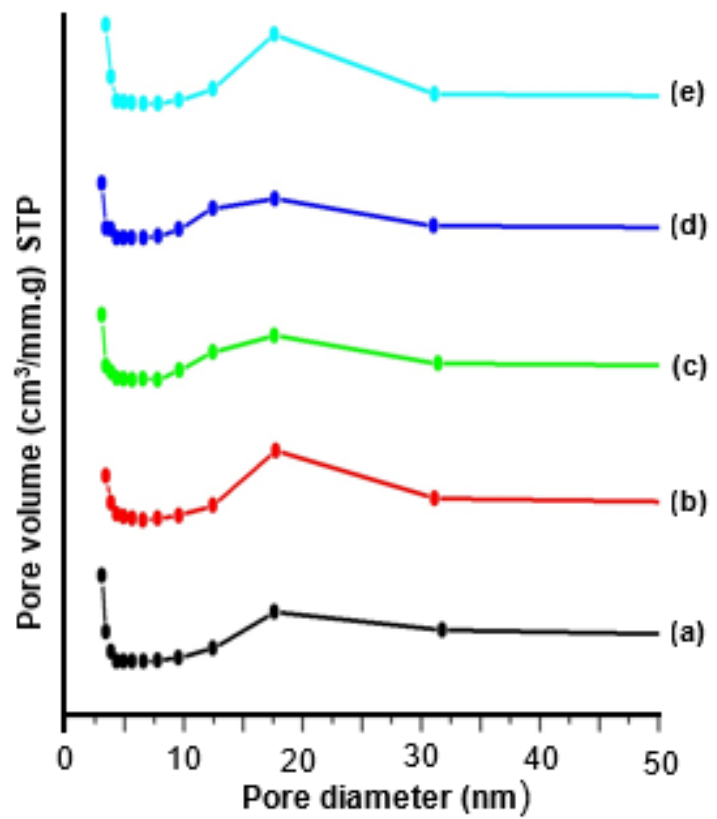

Fig 7. Pore size distribution of AAM sample (a) AAM 0.8; (b) 1.0 ; (c) 1.2 ; (d) 1.4; and (e) 1.5

caused by the presence of capillary condensation on mesoporous walls [21].

The pore size distribution of all AAM samples determined by the BJH method (Barrett, Joiner, Halenda) is shown in Fig. 7. Based on the pore size distribution curves for all AAM samples, the observed bimodal peaks indicate the presence of two pore size groups, the first is in the pore diameter range of about $3.05-3.42 \mathrm{~nm}$ and the second is at about 17.60-17.70 $\mathrm{nm}$. These results indicate that the pore diameter of the resulting aluminosilicate sample is in the mesoporous size range $(2-50 \mathrm{~nm})$, thus the resulting aluminosilicate sample is a mesoporous solid.

Table 4 lists the surface area (BET), pore diameter, and mesoporous volume of the resulting aluminosilicate sample. Based on the data in the table, it can be seen that the surface area of the mesoporous aluminosilicate samples is in the range of 362.55 to $445.71 \mathrm{~m}^{2} / \mathrm{g}$. The pore diameters of all of the resulting aluminosilicate samples are in the range of 3.05 to $17.70 \mathrm{~nm}$ with pore volume ranging from 0.97 to $1.09 \mathrm{~cm}^{3} / \mathrm{g}$.

\section{CONCLUSION}

In conclusion, amorphous mesoporous aluminosilicates can be synthesized from Bintan's red mud as alumina and silica sources by alkali fusion treatment to extract alumina and silica. The condition of alkali fusion treatment by ratio composition of $\mathrm{NaOH}$ : red mud variation $0.8 ; 1.0 ; 1.2 ; 1.4$ and 1.5 . The synthesis condition is the ratio composition of 1 $\mathrm{SiO}_{2}: 0.0125 \quad \mathrm{Al}_{2} \mathrm{O}_{3}: 0.2$ TPAOH:38 $\mathrm{H}_{2} \mathrm{O}$. Amorphous mesoporous aluminosilicates synthesized by this method have a high purity. The synthesized amorphous mesoporous aluminosilicate product is a mesoporous solid characterized by the pore size distribution in all samples ranging from 3.05-3.42 and 17.60-17.70 $\mathrm{nm}$. The highest surface area of the ASM samples is in the AAM 1.5 sample with a surface area of $445.71 \mathrm{~m}^{2} / \mathrm{g}$. The sample pore volume of ASM 1.4 is the highest of $1.09 \mathrm{~cm}^{3} / \mathrm{g}$.

\section{ACKNOWLEDGEMENT}

The authors would like to acknowledge the support from Ministry of Research and Higher Education, Indonesia, under "PUPT" research grant No. 003246.18/IT2.11/PN.08/2015-2017.

\section{REFERENCES}

[1] Sutar, H., Mishra, S.C., Sahoo, S.K., Chakraverty, A.P., and Maharana, H., 2014, Progress of red mud utilization: An overview, Am. Chem. Sci. J., 4 (3), 255-279.

[2] Wang, S., Ang, H., and Tadé, M., 2008, Novel applications of red mud as coagulant, adsorbent and catalyst for environmentally benign processes, Chemosphere, 72 (11), 1621-1635.

[3] Sushil, S., and Batra, V.S., 2008, Catalytic applications of red mud, an aluminium industry waste: A review, Appl. Catal., B, 81 (1-2), 64-77.

[4] Kumar, S., Kumar, R., and Bandopadhyay, A., 2006, Innovative methodologies for the utilisation of wastes from metallurgical and allied industries, Resour. Conserv. Recycl., 48 (4), 301-314. 
[5] Jiakuan, Y., Dudu, Z., Bo, X., and Xiuping, W., 2004, Study on glass-ceramics mostly made from red mud and fly ash, Glass Enamel, 32 (5), 9-11.

[6] Gök, A., Omastová, M., and Prokeš, J., 2007, Synthesis and characterization of red mud/polyaniline composites: Electrical properties and thermal stability, Eur. Polym. J., 43 (6), 24712480.

[7] Tor, A., Danaoglu, N., Arslan, G., and Cengeloglu, Y., 2009, Removal of fluoride from water by using granular red mud: Batch and column studies, J. Hazard. Mater., 164 (1), 271-278.

[8] Pontikes, Y., Nikolopoulos, P., and Angelopoulos, G., 2007, Thermal behaviour of clay mixtures with bauxite residue for the production of heavy-clay ceramics, J. Eur. Ceram. Soc., 27 (2-3), 16451649.

[9] Pera, J., Boumaza, R., and Ambroise, J., 1997, Development of a pozzolanic pigment from red mud, Cem. Concr. Res., 27 (10), 1513-1522.

[10] Ramdhani, E.P., Wahyuni, T., Ni'mah, Y.L., Suprapto, S., and Prasetyoko, D., 2018, Extraction of alumina from red mud for synthesis of mesoporous alumina by adding $\mathrm{CTABr}$ as mesoporous directing agent, Indones. J. Chem., In Press.

[11] Xu, L., Wu, S., Guan, J., Ma, Y., Song, K., Xu, H., Xu, C., Wang, Z., and Kan, Q., 2008, Synthesis, characterization and catalytic activity of a novel mesoporous aluminosilicate catalyst prepared by a citric acid route, Catal. Commun., 9 (10), 19701973.

[12] Varişli, D., Tokay, K.C., Çiftçi, A., Doğu, T., and Doğu, G., 2009, Methanol dehydration reaction to produce clean diesel alternative dimethylether over mesoporous aluminosilicate-based catalysts, Turk. J. Chem., 33 (3), 355-366.

[13] El-Safty, S., Shahat, A., Ogawa, K., and Hanaoka, T., 2011, Highly ordered, thermally/hydrothermally stable cubic la3d aluminosilica monoliths with low silica in frameworks, Microporous Mesoporous Mater., 138 (1-3), 51-62.

[14] Twaiq, F.A., Zabidi, N.A.M., Mohamed, A.R., and Bhatia, S., 2003, Catalytic conversion of palm oil over mesoporous aluminosilicate MCM-41 for the production of liquid hydrocarbon fuels, Fuel Process. Technol., 84 (1), 105-120.

[15] Hartati, H., Prasetyoko, D., Santoso, M., Bahruji, H., and Triwahyono, S., 2014, Highly active aluminosilicates with a hierarchical porous structure for acetalization of 3,4dimethoxybenzaldehyde, Jurnal Teknologi, 69 (5), 25-30.

[16] Han, C., Wang, H., Zhang, L., Li, R., Zhang, Y., Luo, Y., and Zheng, X., 2011, Characterization and investigation on the difference of hydrothermal stability for ordered mesoporous aluminosilicate sieves, Adv. Powder Technol., 22 (1), 20-25.

[17] Zhou, C., Sun, T., Gao, Q., Alshameri, A., Zhu, P., Wang, H., Qiu, X., Ma, Y., and Yan, C., 2014, Synthesis and characterization of ordered mesoporous aluminosilicate molecular sieve from natural halloysite, J. Taiwan Inst. Chem. Eng., 45 (3), 1073-1079.

[18] Sun, C., Zhang, F., Wang, A., Li, S., and Cheng, F., 2015, Direct synthesis of mesoporous aluminosilicate using natural clay from low-grade potash ores of a salt lake in qinghai, china, and its use in octadecylamine adsorption, Appl. Clay Sci., 108, 123-127.

[19] Miao, S., Liu, Z., Ma, H., Han, B., Du, J., Sun, Z., and Miao, Z., 2005, Synthesis and characterization of mesoporous aluminosilicate molecular sieve from K-feldspar, Microporous Mesoporous Mater., 83 (1-3), 277-282.

[20] Simanjuntak, W., Sembiring, S., Manurung, P., Situmeang, R., and Low, I.M., 2013, Characteristics of aluminosilicates prepared from rice husk silica and aluminum metal, Ceram. Int., 39 (8), 9369-9375.

[21] Qoniah, I., Prasetyoko, D., Bahruji, H., Triwahyono, S., Jalil, A.A., and Purbaningtias, T.E., 2015, Direct synthesis of mesoporous aluminosilicates from Indonesian kaolin clay without calcination, Appl. Clay Sci., 118, 290-294.

[22] Borra, C.R., Pontikes, Y., Binnemans, K., and Van Gerven, T., 2015, Leaching of rare earths from bauxite residue (red mud), Miner. Eng., 76, 20-27.

[23] Du, C., and Yang, H., 2012, Investigation of the physicochemical aspects from natural kaolin to AlMCM-41 mesoporous materials, J. Colloid Interface Sci., 369 (1), 216-222.

[24] Gregg, S.J., Sing, K.S.W., and Salzberg, H., 1967, Adsorption surface area and porosity, $J$. Electrochem. Soc., 114 (11), 279C. 